\title{
Ocean acidification does not affect magnesium composition or dolomite formation in living crustose coralline algae, Porolithon onkodes in an experimental system
}

\author{
M. C. Nash ${ }^{1}$, S. Uthicke ${ }^{2}$, A. P. Negri ${ }^{2}$, and N. E. Cantin ${ }^{2}$ \\ ${ }^{1}$ Research School of Physics, Australian National University, Canberra, 0200, Australia \\ ${ }^{2}$ Australian Institute of Marine Science, Townsville, Queensland, 4810, Australia \\ Correspondence to: M. C. Nash (merinda.nash@anu.edu.au) \\ Received: 8 December 2014 - Published in Biogeosciences Discuss.: 21 January 2015 \\ Revised: 23 June 2015 - Accepted: 30 June 2015 - Published: 14 September 2015
}

\begin{abstract}
There are concerns that $\mathrm{Mg}$-calcite crustose coralline algae (CCA), which are key reef builders on coral reefs, will be most susceptible to increased rates of dissolution under higher $p \mathrm{CO}_{2}$ and ocean acidification. Due to the higher solubility of $\mathrm{Mg}$-calcite, it has been hypothesised that magnesium concentrations in CCA Mg-calcite will decrease as the ocean acidifies, and that this decrease will make their skeletons more chemically stable. In addition to Mg-calcite, CCA Porolithon onkodes, the predominant encrusting species on tropical reefs, can have dolomite $\left(\mathrm{Ca}_{0.5} \mathrm{Mg}_{0.5} \mathrm{CO}_{3}\right)$ infilling cell spaces which increases their stability. However, nothing is known about how bio-mineralised dolomite formation responds to higher $p \mathrm{CO}_{2}$. Using $P$. onkodes grown for 3 and 6 months in tank experiments, we aimed to determine (1) if mol\% $\mathrm{MgCO}_{3}$ in new crust and new settlement was affected by increasing $\mathrm{CO}_{2}$ levels (365, 444, 676 and $\left.904 \mu \mathrm{atm}\right)$, (2) whether bio-mineralised dolomite formed within these time frames, and (3) if so, whether this was effected by $\mathrm{CO}_{2}$. Our results show that there was no significant effect of $\mathrm{CO}_{2}$ on mol \% $\mathrm{MgCO}_{3}$ in any sample set, indicating an absence of a plastic response under a wide range of experimental conditions. Dolomite within the CCA cells formed within 3 months and dolomite abundance did not vary significantly with $\mathrm{CO}_{2}$ treatment. While evidence mounts that climate change will impact many sensitive coral and CCA species, the results from this study indicate that reef-building $P$. onkodes will continue to form stabilising dolomite infill under near-future acidification conditions, thereby retaining its higher resistance to dissolution.
\end{abstract}

\section{Introduction}

Determining the influence of ocean acidification from increasing $\mathrm{CO}_{2}$ concentrations on mineral formation of crustose coralline algae (CCA) is not only important to understand potential changes in CCA and their reef building capacity in the future, but also to understand the past. As atmospheric carbon dioxide $\left(\mathrm{CO}_{2}\right)$ concentrations increase, fundamental changes to the ocean's chemistry follow. Seawater $\mathrm{pH}$ and the carbonate saturation state $(\Omega)$ decrease, thus increasing the solubility of $\mathrm{CaCO}_{3}$ skeletons. Current projections are that by the end of this century, if anthropogenic $\mathrm{CO}_{2}$ emissions continue unabated, tropical surface seawater pH will drop by $0.3-0.4$ units to $\sim \mathrm{pH} 7.8$ (Orr, 2011). Marine organisms forming carbonate skeletons are susceptible to increased rates of dissolution as $\mathrm{pH}$ declines (reviewed in Howard et al., 2012). There are concerns that CCA will be one of the first reef-building organisms to suffer as $\mathrm{CO}_{2}$ rises (e.g. Diaz-Pulido et al., 2012), due to the higher solubility of their skeleton. The possibility has also been raised that CCA may decrease their uptake of $\mathrm{Mg}$ to form more stable and lower $\mathrm{Mg}$-calcite in response to higher $\mathrm{CO}_{2}$ concentrations (e.g. Andersson et al., 2008; Ries, 2011).

Experimental data on the impacts of $\mathrm{pH}$ on $\mathrm{Mg}$ uptake by tropical CCA are limited. The branching coralline Neogoniolithon demonstrated a decreased magnesium concentration in severely low pH conditions (Ries, 2011). However, CCA Porolithon onkodes transplanted into low $\mathrm{pH}$ treatments for 8 weeks did not exhibit any Mg composition change with pH in new surface tissue (Diaz-Pulido et al., 2014). Temperate coralline Corallina elongata had a variable response with 
new growth on existing branches not exhibiting a response to elevated $\mathrm{CO}_{2}$ whereas new structures grown during the experiment did have decreased $\mathrm{Mg}$ content in higher $\mathrm{CO}_{2}$ treatments (Egilsdottir et al., 2012). Temperate rhodoliths Lithothamnion glaciale did not change $\mathrm{Mg}$ content in different $\mathrm{CO}_{2}$ treatments while living. However, a significant decrease in the $\mathrm{Mg}$ content in low $\mathrm{pH}$ compared to dead thalli in the same treatment raised the possibility that there was a biological response (Kamenos et al., 2013). Recently it was discovered that tropical CCA P. onkodes commonly possess additional $\mathrm{Mg}$ minerals dolomite $\left(\mathrm{Mg}_{0.5} \mathrm{Ca}_{0.5} \mathrm{CO}_{3}\right)$ and magnesite $\left(\mathrm{MgCO}_{3}\right)$ infilling cells in the crust (Nash et al., 2011). This additional mineralisation significantly reduces rates of skeletal dissolution compared to $P$. onkodes without dolomite cell infill (Nash et al., 2013a). A combination of high $\mathrm{CO}_{2}$ and increased temperature over 8 weeks led to a $\sim 300 \%$ increase in the relative quantity of dolomite in $P$. onkodes crust transplanted into the treatment conditions (Diaz-Pulido et al., 2014). This was due to endolithic cyanobacteria, Mastigocoleus sp., removing calcium from the Mg-calcite skeleton but not from dolomite, leading to destruction of $\mathrm{Mg}$-calcite and a relative increase in dolomite. It could not be determined if there was also an increase in the formation of primary dolomite.

When CCA grow to form the thick crust crucial to cementing together the structural reef framework, the new growth extends upwards leaving the old growth as a white crust without pink photosynthetic pigment. The surface of the CCA is the epithallus and the pink colouration in the top few hundred microns is due to the presence of pigmented photosynthetic tissue within the Mg-calcite skeleton. In other species of corallines, the epithallus has been shown to slough off (Pueschel et al., 2005) and be grazed by chitons and limpets (Adey et al., 2013). The crust underneath (perithallus) has been shown in other species of CCA to form as cell by cell growth downward from the meristem cells (growth layer between epithallus and perithallus) (Adey et al., 2013). Thus, the white crust is a product of meristem growth, and not a build-up of old epithelial growth. It is in this important reefstructure forming white crust that dolomite infill is abundant (Nash et al., 2011; Diaz-Pulido et al., 2014). As yet, there have been no experiments to determine the impact of $\mathrm{CO}_{2}$ levels on $\mathrm{mol}_{\%} \mathrm{MgCO}_{3}$ and dolomite formation in the white crust grown in differing $\mathrm{CO}_{2}$ treatments.

There is a noted correlation of sedimentary dolomite abundance and greenhouse conditions (high temperature, high $\mathrm{CO}_{2}$ ) over the geological past (e.g. MacKenzie et al., 2008; Wilkinson and Given, 1986). To understand the past, it is necessary to separate the roles that $\mathrm{CO}_{2}$ and temperature may have had on constraining dolomite concentration. Biomineralised dolomite has been found in modern environments (Vasconcelos and Mackenzie, 1997; Nash et al., 2011), but it is not known how changes in $\mathrm{CO}_{2}$ concentrations may affect formation of bio-mineralised dolomite. This study describes the first experiments that constrain the role of $\mathrm{CO}_{2}$ on CCA bio-mineralised dolomite formed in differing $\mathrm{CO}_{2}$ environments.

The aims of this investigation were threefold; (1) to identify any changes in $\mathrm{mol} \% \mathrm{MgCO}_{3}$ in new settlement and new white crust of $P$. onkodes grown in Pre-industrial, Control (present day), Medium (near future) and High (end of century) $\mathrm{CO}_{2}$ (IPCC, 2007) conditions over 3 and 6 months; (2) to determine whether CCA bio-mineralised dolomite is formed within these time frames; (3) to determine if the $\mathrm{CO}_{2}$ concentration affects CCA bio-mineralised dolomite formation.

\section{Methods}

\subsection{Experiment}

Fragments of live $P$. onkodes were collected from the upper reef crests (2-3 m depth) of Davies Reef $\left(18^{\circ} 49.29^{\prime} \mathrm{S}\right.$, $147^{\circ} 37.99^{\prime}$ E), Great Barrier Reef in August 2012. To eliminate open carbonate surfaces, CCA chips $(\sim 1 \mathrm{~cm}$ diameter $)$ were sealed around the sides and base in non-toxic underwater glue (Mr. Sticky's, Fair Oaks, CA) and attached to PVC slides (only the top live surfaces were exposed to seawater). Blank slides were also added to the system to identify and track new CCA settlement. Slides were mounted in custom perspex holders which were held in place on aquarium walls using magnets. The experimental system used was described in Uthicke et al., (2013). Briefly, fresh filtered seawater $(0.4 \mathrm{~mm})$ was added to three replicate tanks (for each treatment) replacing the water twice daily. Flow rates in each experimental tank were $12 \mathrm{~L} \mathrm{~min}^{-1}$. In addition to a present day $\left(\mathrm{pH}_{T} 8.0\right.$ target, measured mean $7.96 \pm 0.04 \mathrm{SE} \mathrm{CO}_{2}$ : $444 \pm 37 \mu \mathrm{atm}$ ), mid-century 2050 (future $\mathrm{pH}_{T} 7.9$ target, measured mean $\left.7.90 \pm 0.04 \mathrm{SE} \mathrm{CO}_{2}: 676 \pm 37 \mu \mathrm{atm}\right)$ and end of century 2100 (future $\mathrm{pH}_{T} 7.75$ target, measured mean $\left.7.77 \pm 0.06 \mathrm{SE} \mathrm{CO}_{2} 904 \pm 32 \mu \mathrm{atm}\right)$ target acidification treatments, this experiment also included a pre-industrial treatment (past $\mathrm{pH}_{T} 8.14$ target, measured mean $8.09 \pm 0.04 \mathrm{SE}$ $\mathrm{CO}_{2}: 365 \pm 37 \mu \mathrm{atm}$ ). Acidified treatments were achieved by bubbling $\mathrm{CO}_{2}$ into sump tanks with solenoid valves (SMC pneumatics) and controlled with $\mathrm{pH}$ setpoints, while the preindustrial treatment was achieved by passing a stream of atmospheric air through two soda lime canisters and mixing the low- $\mathrm{CO}_{2}$ scrubbed air with the incoming seawater in a counter current exchange tower prior to flowing into each experimental tank. Temperatures were controlled (Avg. $26.1 \pm 0.15^{\circ} \mathrm{C}$ ) with a heater-chiller unit (EvoHeat DHP40). $\mathrm{pH}$ and temperature were monitored continuously (30 s sampling rate) with ISFET type $\mathrm{pH}$ probes (Endress Hauser CPS471D). Seawater $\mathrm{CO}_{2}$ concentrations were measured using a LiCor (LI-840A) $\mathrm{CO}_{2} / \mathrm{H}_{2} \mathrm{O}$ analyser. This experiment was conducted within the outdoor aquarium facility at the Australian Institute of Marine Science under natural daily light cycles during the Austral summer (October-April). Out- 


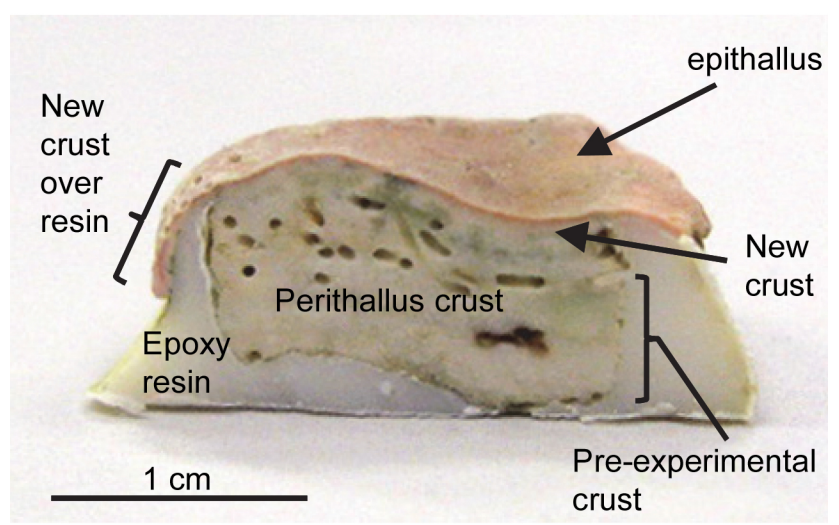

Figure 1. Example of $P$. onkodes after 3 months. New crust overgrowing resin used for XRD.

door light intensities were reduced with $70 \%$ UV blocking green shade cloth to an average intensity of $210 \pm 12 \mu \mathrm{mol}$ photons $\mathrm{m}^{-2} \mathrm{~s}^{-1}$, with a daily maximum of $330 \mu \mathrm{mol}$ photons $\mathrm{m}^{-2} \mathrm{~s}^{-1}$. These light intensities correspond to the daily average light intensity on shallow reefs.

\subsection{Sample selection}

Subsets of CCA's in resin were removed from the tanks after 3 and 6 months. The settlement slides were removed after 6 months. Samples were randomly selected from these for XRD analyses. New crust from the resin-embedded CCA's was sampled by breaking off the crust that overgrew the resin. This ensured that only crust formed during the experiment was included in the new crust analyses. The new crust typically had a thin layer ( $\sim 0.5$ to $2 \mathrm{~mm}$ ) of white crust overlain by a layer of pink photosynthetic perithallus (Fig. 1). CCA that had settled on the plastic slides after 6 months had only pink crust and there was no white crust underneath. Typically for the new settlement CCA, 2-4 settlement patches were required to obtain sufficient material for analysis by $\mathrm{XRD}$, thus each individual result for new settlement is an average of several CCA patches. These CCA had not reached reproductive stage and could not be identified. For the 6month experiment, CCA's in resin from the control tanks were unavailable for mineral analysis.

\subsection{Analyses}

CCA were cut using a bench-top saw with a $2 \mathrm{~mm}$ thick diamond-impregnated blade. A slice through the middle of each 3-month sample was kept for SEM. Scanning Electron Microscopy-Energy Dispersive Spectroscopy (SEM-EDS) was undertaken at the Australian National University using a Ziess UltraPlus field emission scanning electron microscope (FESEM) equipped with an HKL electron backscatter diffraction (EBSD) operated at $15 \mathrm{kV}, 11 \mathrm{~mm}$ working distance. CCA were mounted using carbon tape and carbon coated. Subsampling for XRD was taken from the matching side of the remainder crust. Samples (>20 mg) were milled by hand in an agate mortar. Fluorite was added as an internal standard. Acetone was not used as this has been found to react with the pink pigmented surface samples. Samples were mounted onto quartz low background holders. Scan range was $25-33^{\circ} 2$-theta, step size $0.02^{\circ}$ 2-theta and a scan speed of $1^{\circ} \mathrm{min}^{-1}$. Xray diffraction and mineral determination was carried out following Nash et al. (2013b). Simply, this method uses the asymmetry off the higher 2-theta side of the Mg-calcite XRD peak to detect dolomite. The more asymmetry the greater proportion of dolomite in the crust. A shoulder off the higher 2-theta side of the peak indicates that magnesite $\left(\mathrm{MgCO}_{3}\right)$ is also present. This asymmetry and shoulder is captured with the asymmetry mol \% measurement. The asymmetry mol $\%$ is used to compare for differences in relative dolomite and magnesite quantities (Nash et al., 2013b). It is not a measurement of absolute quantity. However, when compared to mineral quantities determined using standard curve fitting techniques, the differences in asymmetry reflect well the differences in dolomite and magnesite quantities (as used in Diaz-Pulido et al., 2014). See Fig. S1 in Supplement for example scans.

\subsection{Dolomite terminology}

Stoichiometric dolomite is $50 \mathrm{~mol} \% \mathrm{MgCO}_{3}$. Typically dolomite formed under high temperature is stoichiometric and well ordered (Kaczmarek and Sibley, 2011). Ordering occurs where there are alternating layers of $\mathrm{MgCO}_{3}$ and $\mathrm{CaCO}_{3}$ in the calcite lattice, whereas completely disordered dolomite has $\mathrm{Mg}$ randomly substituting for $\mathrm{Ca}$ in the lattice. Sedimentary dolomite formed at sea surface temperature and pressure and not subject to post-deposition burial and metamorphism, is typically non-stoichiometric with a range of 37.5 to $52 \mathrm{~mol} \% \mathrm{MgCO}_{3}$ (Jones et al., 2001) and not well ordered (Kaczmarek and Sibley, 2011). Synthetically formed disordered dolomite has been shown to be unstable in aqueous solutions and therefore it is thought that disordered dolomite cannot form or persist in the open marine environment in which sedimentary dolomite forms (Gaines, 1977). A variety of descriptions exist for dolomite that deviates from stoichiometric and are perfectly ordered: non-ideal, poorly ordered or disordered, protodolomite, pseudo-dolomite and calcium-enriched dolomite (Gaines, 1977).

Here we use the term dolomite to represent magnesium calcite in the range $38-62 \mathrm{~mol} \% \mathrm{MgCO}_{3}$, as measured for P. onkodes dolomite (Nash et al., 2011) without inferring cation ordering status, that is, whether it is ordered, disordered or partially ordered. The P. onkodes dolomite has previously been demonstrated via etching experiments and natural dissolution processes to have a delayed dissolution reaction compared to Mg-calcite and has different crystal forms to Mg-calcite (Nash et al., 2013a). Furthermore, it has been documented that Mg-calcite in 
Table 1. Two factor analysis of variance (ANOVA) testing for difference in mol $\% \mathrm{MgCO}_{3}$ and Asymmetry indicating dolomite, between different $\mathrm{CO}_{2}$ treatments (Factor Treatment) and experimental growth vs. pre-experimental growth (Factor Type). No significant difference (bold) related to $\mathrm{CO}_{2}$ treatments, but significant difference between experimental and pre-experimental growth for both mol \% $\mathrm{MgCO}_{3}$ and dolomite asymmetry.

\begin{tabular}{|c|c|c|c|c|c|c|c|c|}
\hline & \multirow[b]{2}{*}{ DF } & \multicolumn{2}{|c|}{ Mol \% } & \multirow[b]{2}{*}{$p$} & \multirow[b]{2}{*}{ DF } & \multicolumn{2}{|c|}{ Asymmetry } & \multirow[b]{2}{*}{$p$} \\
\hline & & MS & $\mathrm{F}$ & & & MS & $\mathrm{F}$ & \\
\hline Treatment & 2 & $1.76 \mathrm{E}-05$ & 0.77 & 0.4754 & 2 & $1.98 \mathrm{E}-04$ & 0.55 & 0.582 \\
\hline Type & 1 & $6.52 \mathrm{E}-04$ & 28.54 & $<0.001$ & 1 & $7.00 \mathrm{E}-03$ & 19.57 & $<0.001$ \\
\hline $\operatorname{Tr} \times$ Type & 2 & 0.49 & 0.61972 & 0.1195 & 2 & 0.35 & 0.7082 & 0.099 \\
\hline Residual & 21 & & & & 22 & $3.58 \mathrm{E}-04$ & & \\
\hline
\end{tabular}

P. onkodes ranges up to $\sim 26 \mathrm{~mol} \% \mathrm{MgCO}_{3}$ (Nash et al., 2011) and there is a well-defined division from dolomite which commences at $\sim 38 \mathrm{~mol} \% \mathrm{MgCO}_{3}$. Experimental work has demonstrated that cyanobacteria (Mastigocoleus sp.) which bio-erode limestone by removing calcium, do not take calcium from dolomite rock (Ramirez-Reinat and Garcia-Pichel, 2012). Experiments on live dolomite-forming $P$. onkodes also show that the same cyanobacteria remove calcium from $\mathrm{Mg}$-calcite but do not remove calcium from the $P$. onkodes dolomite. P. onkodes $\mathrm{Mg}-\mathrm{C}$ and $P$. onkodes dolomite have distinctly different physical properties and $P$. onkodes dolomite reacts under chemical (Nash et al., 2013a) and bioerosion conditions (Diaz-Pulido et al., 2014) comparably to dolomite rock. We have been unable to confirm the presence of ordering peaks by XRD for the dolomite within the living P. onkodes (Nash et al., 2013b). However, the persistence of the CCA dolomite in aqueous environments and its greater resistance to dissolution than $\mathrm{Mg}$-calcite (Nash et al., 2013a) suggests there is some degree of ordering and $P$. onkodes dolomite is not the same mineral as Mg-calcite which theoretically becomes less stable with greater $\mathrm{Mg}$-substitution (Andersson et al., 2008). Therefore, we consider that referring to the CCA mineral as dolomite, with the caveat that this is without inferring cation-ordering status is the most appropriate identification for the mineral at this time. Our decision to use this terminology for $\mathrm{Mg}-\mathrm{C}>38 \mathrm{~mol} \% \mathrm{MgCO}_{3}$ is supported by recently published clarification on terminology for Ca-Mg carbonates (Zhang et al., 2015).

\subsection{Crust terminology}

The term "pre-experimental growth" refers to crust grown in situ at Davies reef prior to collection for the experiment. The new crust (experimental) is the growth above the height of the resin. The "new crust" terminology is used because this includes both the crust of the perithallus and the surface epithallus. There may also be re-growths within the perithallus that includes hypothelial cells and alteration to aragonite (see for example Fig. 8). The new settlement on slides in the 6month treatment was predominantly pink indicating absence of a well-developed perithallus. However, when CCA settle, the first cells laid down are hypothelial cells growing lengthways parallel to the surface and then vertical growth of the epithallus, followed by the perithallus (Steneck, 1986). A scraping sample would include not only epithallus but also minor hypothallus and possibly the start of a perithallus. For this reason we use the term new settlement rather than epithallus

\subsection{Statistical analysis}

We tested for differences between $\mathrm{CO}_{2}$ treatments and sample type using two factor analysis of variance (ANOVA). Different $\mathrm{CO}_{2}$ treatments (Factor Treatment) and experimental growth versus pre-experimental growth (Factor Type) were both used as fixed factors. Residual plots and boxplots confirmed that there were no deviations from ANOVA assumptions. Because slightly unequal sample sizes were used in each treatment, we applied marginal sums of squares for the F-tests.

\section{Results}

\subsection{Mineral composition in different $\mathrm{CO}_{2}$ treatments}

We investigated the mineral composition of CCA exposed to different OA conditions for 3 and 6 months in a long-term aquarium experiment. There were no significant differences in mineral composition between any of the $\mathrm{CO}_{2}$ treatments (Table 1). For the new P. onkodes crust formed during the 3month duration (Fig. 2a), the mol $\% \mathrm{MgCO}_{3}$ range is $16.4-$ $16.7 \mathrm{~mol} \% \mathrm{MgCO}_{3}(n=5$ per treatment, averages: Pre 16.6, Control 16.5, Medium 16.4, High $16.7 \mathrm{~mol} \% \mathrm{MgCO}_{3}$ ) (full results Supplement Table S1). This range is only $0.1 \mathrm{~mol} \%$ more than measurement precision (Nash et al., 2011). For the new P. onkodes crust formed over 6 months (Fig. 2b), the $\mathrm{mol} \% \mathrm{MgCO}_{3}$ range was the same as the 3-month crust $16.4-16.7 \mathrm{~mol} \% \mathrm{MgCO}_{3}$, (Pre $16.7 n=5$, Medium 16.4 $n=3$, High $16.5 \mathrm{~mol} \% \mathrm{MgCO}_{3} n=6$ ) (Table S2). Many of the Mg-calcite XRD peaks for both the 3 and 6-month crust demonstrated asymmetry indicating the presence of dolomite (as per Nash et al., 2011, 2012, 2013a, b; Diaz-Pulido et al., 

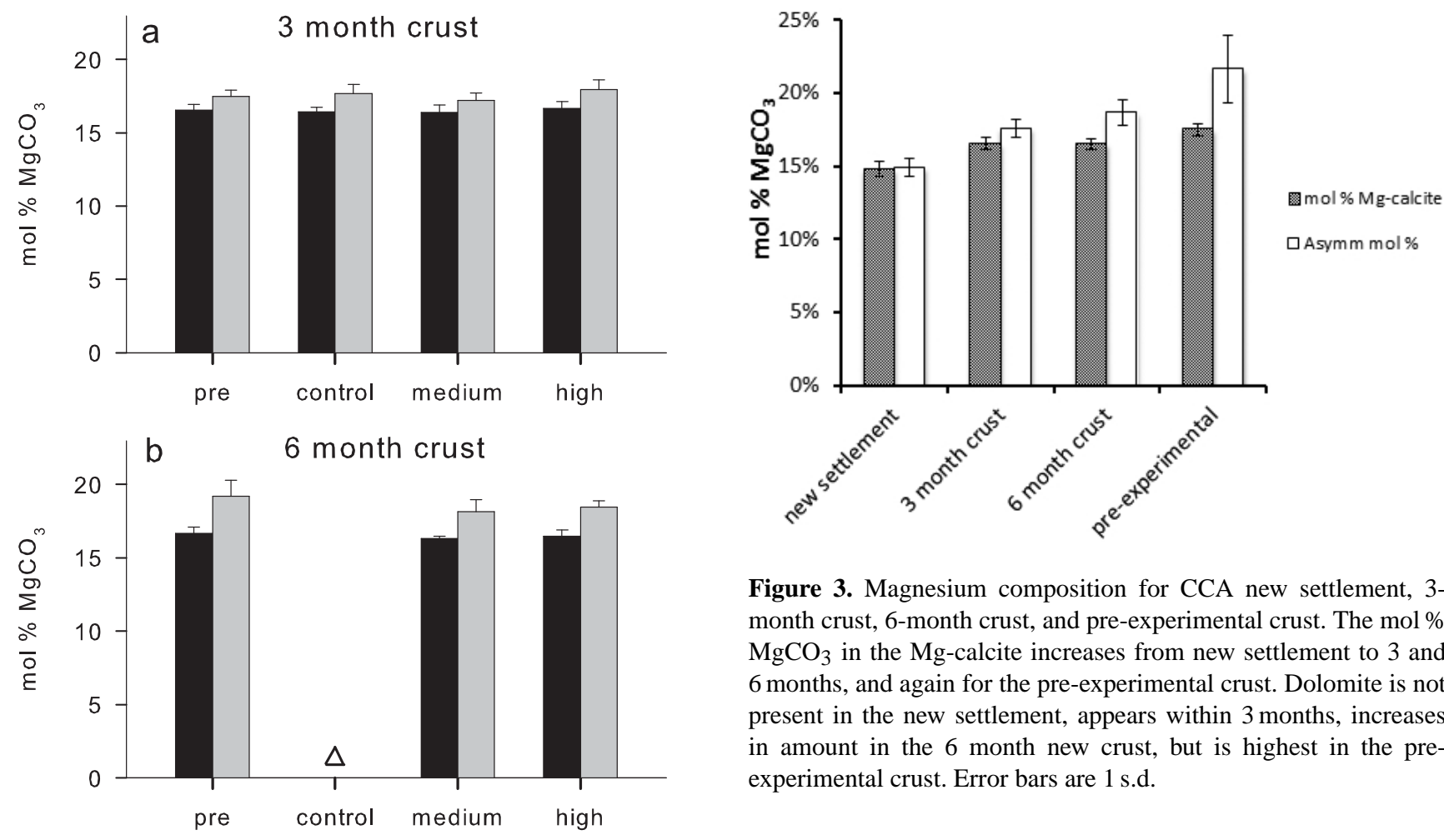

Figure 3. Magnesium composition for CCA new settlement, 3month crust, 6-month crust, and pre-experimental crust. The mol \% $\mathrm{MgCO}_{3}$ in the $\mathrm{Mg}$-calcite increases from new settlement to 3 and 6 months, and again for the pre-experimental crust. Dolomite is not present in the new settlement, appears within 3 months, increases in amount in the 6 month new crust, but is highest in the preexperimental crust. Error bars are 1 s.d.

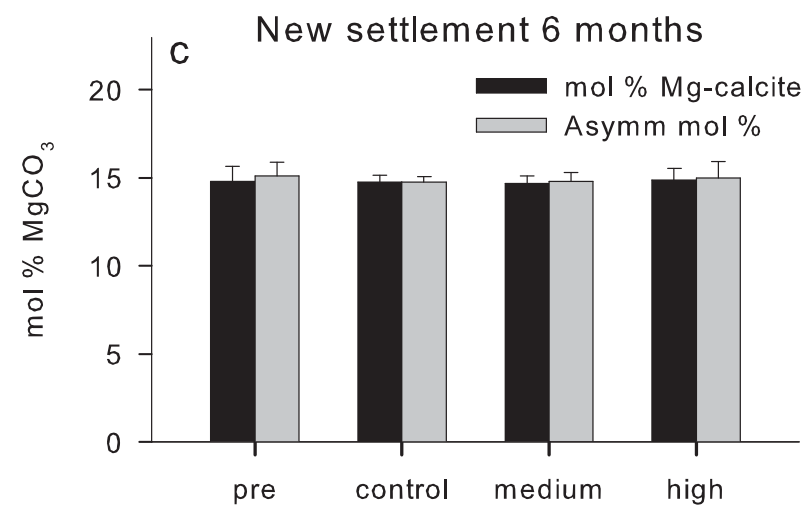

Figure 2. Magnesium composition for experimental growth of $P$. onkodes. $\mathrm{Mol} \%$ is for $\mathrm{Mg}$-calcite $\mathrm{mol} \% \mathrm{MgCO}_{3}$. Asymm mol\% includes influence of dolomite asymmetry on calculated $\mathrm{Mg}$-calcite mol $\% \mathrm{MgCO}_{3}$, the more dolomite present the higher the Asymm mol \%. (a) New crust after 3 months. (b) New crust after 6 months. There was no significant difference between treatments for either the $\mathrm{mol}_{\%} \mathrm{MgCO}_{3}$ or the Asymm mol\% in new crust after 3 or 6 months. Control samples were unavailable for mineral analyses. (c) New settlement after 6 months. As for the new crust, there was no significant difference across the treatments in $\mathrm{mol} \% \mathrm{MgCO}_{3}$. There is no dolomite in the new settlement consistent with the absence of white crust. Error bars are \pm 1 s.d.

2014). There was no significant difference in the dolomite asymmetry related to $\mathrm{CO}_{2}$ treatments (asymmetry test, Table 1). For unidentified CCA that had settled on the slides over 6 months (Fig. 2c), (Table S3) the mol $\% \mathrm{MgCO}_{3}$ ranged from 14.7-14.9 (Pre 14.8 $n=3$, Control $14.7 n=4$, Medium $14.7 n=5$, High $14.9 \mathrm{~mol} \% \mathrm{MgCO}_{3} n=5$ ). The new settlement CCA did not have dolomite, i.e. no peak asymmetry, consistent with the absence of white crust underneath.

\subsection{Mineral compositional differences between crust layers}

As there was no significant difference between treatments, all treatments were combined for each time period. There was a significant difference in $\mathrm{Mg}$ composition between experimental crust and pre-experimental crust. Mg-calcite mol $\% \mathrm{MgCO}_{3}$ was also significantly different for new settlement (pigmented growth without development of white crust) compared to new crust (growth that has developed white crust). The 6 month new settlement (pigmented growth only) at $14.8 \mathrm{~mol} \% \mathrm{MgCO}_{3}$ (Fig. 3) was significantly lower than the $\mathrm{mol} \% \mathrm{MgCO}_{3}$ for the new crusts from the 3 and 6 months new crusts $\left(\sim 16.5 \mathrm{~mol} \% \mathrm{MgCO}_{3}\right)$. The asymmetry indicating dolomite presence was absent from the new growth, but appeared in new white crust within 3 months (Asymm mol \% 17.6) and was higher again for the 6-month new crust (Asymm mol \% 18.7). The $\mathrm{mol} \% \mathrm{MgCO}_{3}$ and asymmetry $\mathrm{mol} \%$ in the pre-experimental $P$. onkodes crust (the crust formed in the natural environment prior to sample collection) were even higher at 17.5 and $21.6 \mathrm{~mol} \% \mathrm{MgCO}_{3}$ respectively (Fig. 3) (full data Table S4). 

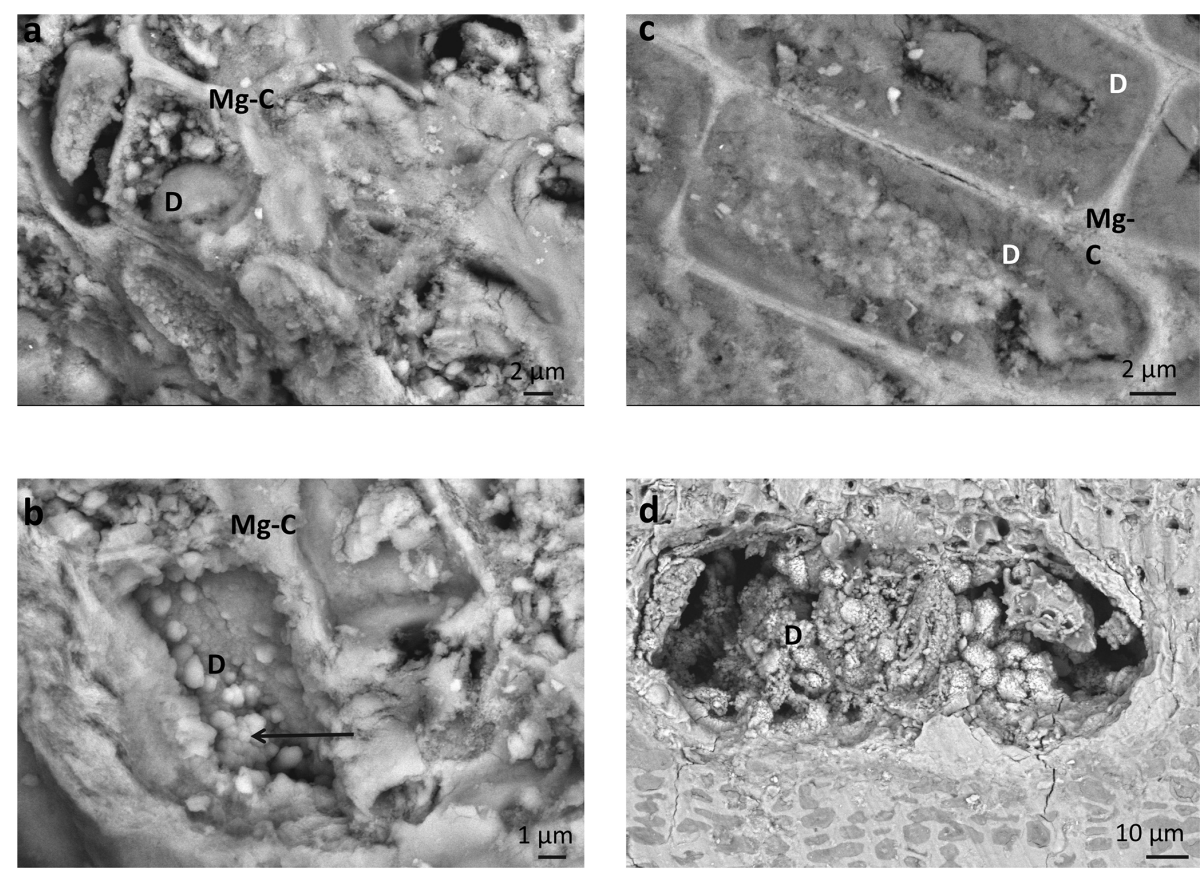

Figure 4. SEM (Backscatter - BSE) of control P. onkodes showing dolomite in experimental and pre-experimental growth. BSE SEM shows the lighter elements, i.e. magnesium, as darker grey and heavier elements, i.e. calcium is pale grey to white. Secondary electron images show the topography of the sample but do not provide information on the elemental composition. EDS measurements are made in the different grey shade areas to measure $\mathrm{Mg}$ composition (range listed in supplement) and this is used to identify the mineral composition. Once the measurements have been made it is possible then to identify dolomite and calcite from the grey shade. (a) Experimental growth, dolomite (D) Dolomite-composition material in cell. This is not the typical cell lining but has been observed in other CCA. Mg-calcite (Mg-C). Scale $=2$ microns. (b) Experimental growth: micro-scale lumpy dolomite lining cell. Scale $=1$ micron. Cell growth in experimental growth is less regular and organised than pre-experimental growth. (c) Dolomite cell lining in pre-experimental growth. Notice the very narrow cell walls. (d) Dolomite infill in a reproductive conceptacle in the old growth. Cells below conceptacle are all in-filled with dolomite. Scale bars: (a) and (c) $=2$ microns, $(\mathbf{b})=1$ micron, $(\mathbf{d})=10$ microns.

\subsection{SEM results}

\subsubsection{Comparison of crust across treatments and experimental/pre-experimental}

Although there was no detected difference in mineral composition across treatments, SEM was undertaken to visualise potential differences in calcification structures between treatments. There was no visible difference in calcified crust detected between CCA from pre-industrial, control or high $\mathrm{CO}_{2}$ treatments. There was, however, a clear difference in the structure of the crust grown during the experimental duration compared to the pre-experimental crust (Figs. 4, 5 and Fig. S2). This difference was observed in control CCA, as well as pre-industrial and high $\mathrm{CO}_{2} \mathrm{CCA}$ indicating the difference was not related to the $\mathrm{CO}_{2}$ levels. Crust formed during the experiment appeared less organised and also appeared structurally less dense (Fig. 6) with cracks and associated gaps in the crust that were not present in the pre-experimental crust. The difference in density was based on observation and was not able to be quantified.
The experimental crust had compressed under the action of the saw used to slice the CCA (Fig. 7). We note that this compression by the saw would have made it difficult to identify any differences in growth structure between the $\mathrm{CO}_{2}$ treatments. Previous work relying on SEM for CCA interpretation has used both saw cutting similar to here (Nash et al., 2011, 2013a, b; Diaz-Pulido et al., 2014), as well as fracturing without any further treatment of the sample (Nash et al., 2013a; Diaz-Pulido et al., 2014). There has not been an observed impact of saw cutting on experimental samples (Diaz-Pulido et al., 2014). However, those previous samples were polished after cutting and fine cracks may have been less obvious due to polishing. The crust features in the pre-experimental crust are comparable to features in other $P$. onkodes analysed using SEM that have been cut, cut and polished or only fractured (Nash et al., 2011, 2013a, b; Diaz-Pulido et al., 2014) and it is unlikely that the use of the saw has introduced an artifact into this study other than to highlight the susceptibility of the experimental crust to crushing compared to pre-experimental crust. 

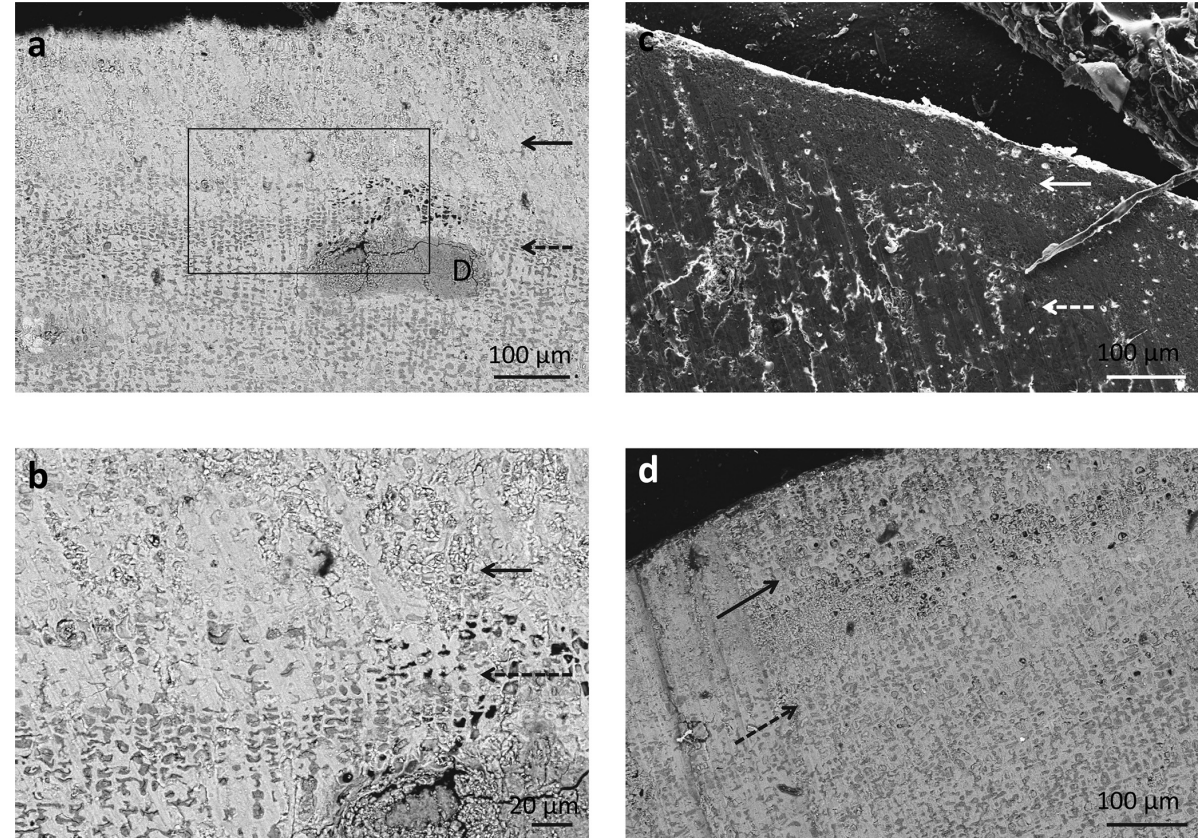

Figure 5. Control $P$. onkodes with experimental growth on pre-experimental growth. (a) (BSE) There is a visible difference in the appearance of experimental crust (black arrow) to the pre-experimental growth (black dashed arrow). The lighter grey of the surface is due to less magnesium (dolomite) infilling the cells that appear as darker grey infill in the pre-experimental lower part of the crust. Black box enlarged in (b). D is dolomitised conceptacle. (b) Close up showing the consistent presence of infill in pre-experimental growth whereas in the new growth regular dolomite cell lining is absent. Also, the $\mathrm{Mg}-\mathrm{C}$ crust itself appears to be less dense with many cracks from the cutting visible in the new growth but not so in the pre-experimental growth. (c) Secondary electron image of control CCA. The pre-experimental growth appears to have a fine opaque organic film covering part of the cut crust (white dashed arrow), but this is not present in the experimental growth (White arrow). (d) Control CCA (BSE) Dashed arrow to pre-experimental growth. Grey cells are dolomite infill. Black arrow to experimental growth, generally an absence of dolomite infill, note line of porosity in transition between pre-experimental and experimental growth. Scale bars: $(\mathbf{a}),(\mathbf{c})$ and $(\mathbf{d})=100$ microns, $(\mathbf{b})=20$ microns.

\subsubsection{Dolomite features}

Dolomite composition determined by SEM-EDS ranged from 37.3 to $59.8 \mathrm{~mol} \% \mathrm{MgCO}_{3}$ (Table S5), comparable to the range identified in previous studies (Nash et al., 2011). There was a delineation along the new experimental growth where dolomite was nearly absent compared to consistent infill in pre-experimental crust (Figs. 5-7, Fig. S3). The structure of dolomite formed in the experimental crust also appeared different to that which formed in the pre-experimental crust (Fig. 4). New growth dolomite did not generally fill the cells as was observed in the pre-experimental growth. In the experimental growth, dolomite was present as lumpy infill or lining (Fig. 4a and b). In the pre-experimental crust, dolomite lined and in-filled most cells (Fig. $4 \mathrm{c}$ and d). In the control CCA the pre-experimental crust had an opaque organic film that was not visible in experimental growth (Fig. 5c), although there was organic material in the cells (Fig. S3).

\subsubsection{Crust damage possibly due to transfer to experimental tanks}

Pre-experimental crust immediately below experimental growth had aragonite cell infill (Fig. 7). In previous work aragonite infill of this type has only been observed at the base of the CCA crust exposed to seawater (Nash et al., 2013a Supplement), or in parts of the skeleton that have been damaged allowing seawater to penetrate. However, we could find no obvious signs of damage to the crust. $P$. onkodes has varied mineralogy throughout the preexperimental crust (Fig. 8) with patches altered to aragonite and dolomite bands. Regrowth in damaged areas within the pre-experimental crust was more dolomite rich than surrounding areas (Fig. 8b), indicating that damage to crust in the open environment had not resulted in a reduction in dolomite formation.

\section{Discussion}

Our results show that over the experimental duration (1) there were no changes in any crust mineral composition 

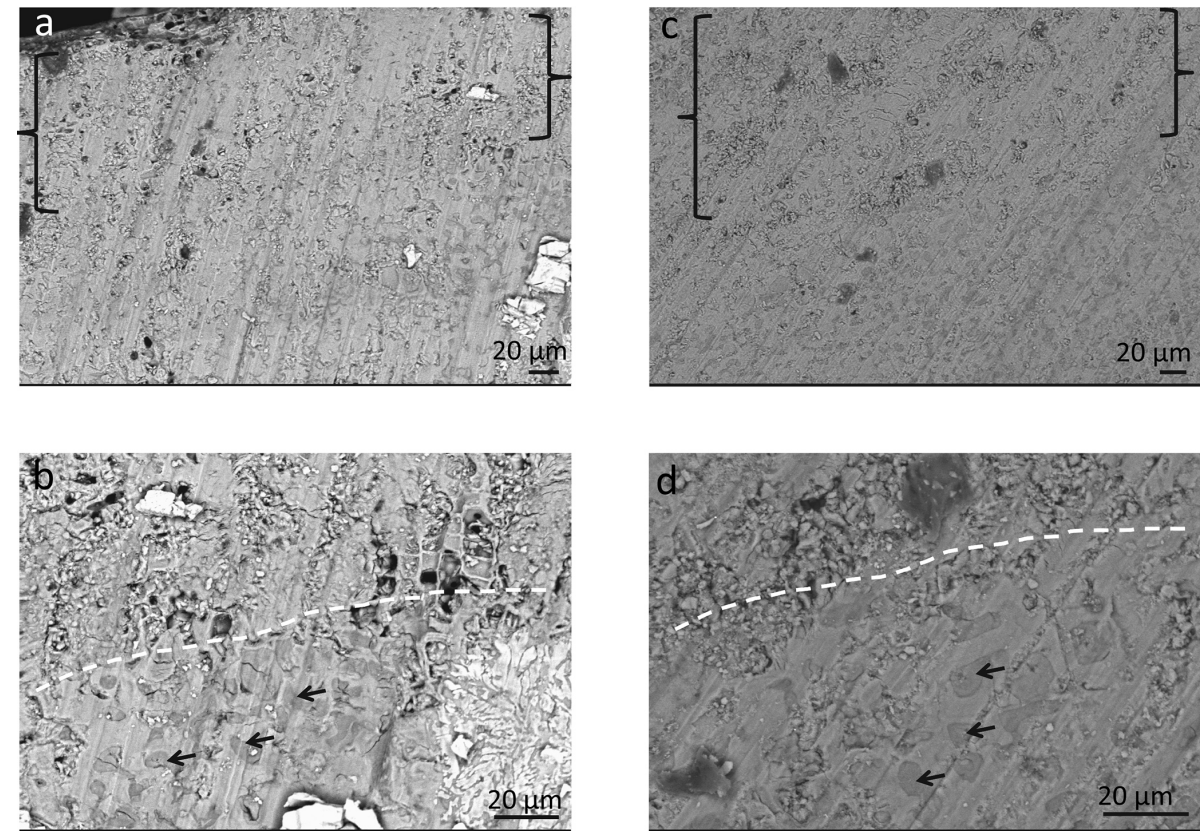

Figure 6. Transition from pre-experimental crust to experimental crust in $P$. onkodes, pre-industrial CCA (a, b) (BSE), high $\mathrm{CO}_{2} \mathrm{CCA}$ (c, d). Transition from pre-experimental growth to experimental identified by following the growth lines from the crust on the resin (not pictured) across the sample. (a) Overview, brackets- new growth. (b) Close up of transition. Crust below dashed line is pre-experimental growth. Dolomite infills cells (black arrows). Above dashed line new growth does not have cells infilled, crust has been damaged by saw cut. (c) Overview of transition to new growth in high $\mathrm{CO}_{2} \mathrm{CCA}$, brackets - new growth. (d) Close up of transition. Similarly to control and pre-industrial CCA, cells in pre-experimental growth are infilled with dolomite (black arrows). Crust above dashed line grew during experiment. Cells are not infilled with dolomite and crust has crushed in S3 under the sawcut. Scale bars (a, b, c) and (d) $=20$ microns. Close up of transition from pre-experimental growth to experimental growth in supplement Fig. 3.

relating to $\mathrm{CO}_{2}$ concentrations; (2) $\mathrm{CCA}$ bio-mineralised dolomite forms within 12 weeks within aquarium conditions; and (3) $\mathrm{CO}_{2}$ concentrations do not affect CCA biomineralised dolomite formation.

\subsection{Magnesium composition and calcification processes}

The higher mol $\% \mathrm{MgCO}_{3}$ for white crust compared to the pigmented new growth layer (new settlement) has been documented previously for P. onkodes (Diaz-Pulido et al., 2014). This higher $\mathrm{mol} \% \mathrm{MgCO}_{3}$ in the white crust suggests that controls on magnesium uptake are different for the white crust (perithallium) than the pigmented surface layers (epithallium).

Considering that CCA crusts are increasingly being used for paleo environmental reconstruction (e.g. Kamenos et al., 2008; Halfar et al., 2013; Caragnano et al., 2014; Darrenougue et al., 2014; Fietzke et al., 2015), it is important to know whether this difference in $\mathrm{Mg}$ composition between the pigment surface and white crust is part of the standard calcification processes of the $P$. onkodes or due to postdepositional change. In this and previous work (Nash et al., 2011, 2013a) portions of the crust that have been diagenetically altered post-deposition have cells in-filled by aragonite or Mg-calcite. Typically the cell walls have not exhibited ev- idence of alteration even when there has clearly been exposure to seawater suggesting the intact cell walls are quite resistant to diagenesis. Probably the epithelial cell walls and perithelial cell walls have differences in the organic material that constrain the Mg uptake. The interfilament and intrafilament (spaces between adjacent cell walls) calcification does not appear to be physically constrained by an organic template in the P. onkodes and Clathromorphum Foslie emend (Nash et al., 2013a; Adey et al., 2013). Mg-calcite crystals are randomly orientated or roughly parallel to the cell walls, which suggests that the controls on calcification and consequently $\mathrm{Mg}$ incorporation may be different again for the interfilament calcification. It seems most likely that the difference in the mol $\% \mathrm{MgCO}_{3}$ for the white crust compared to the pigmented new growth is due to organism-constrained $\mathrm{Mg}$ uptake during the crust development. It cannot be determined from this study whether the Mg is incorporated in its final concentrations as the new cell wall and inter/intra filament calcification is first formed or if there is subsequent $\mathrm{Mg}$ enrichment over days/weeks/months. However, previous work subsampling portions of the CCA crust from the top to the base has not demonstrated any systematic increase in $\mathrm{mol} \% \mathrm{MgCO}_{3}$ (Nash et al., 2013b) suggesting if there is 

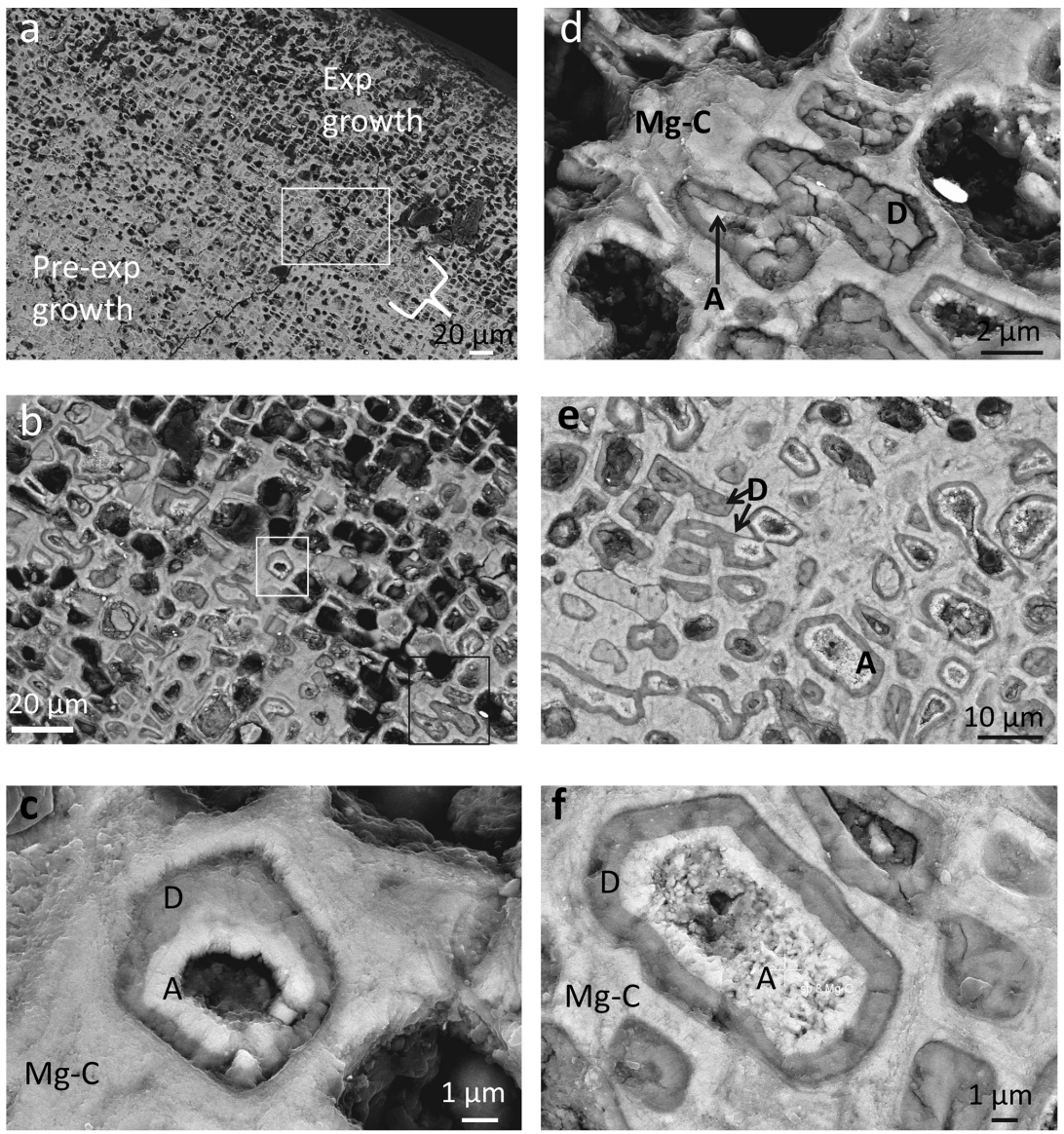

Figure 7. SEM (BSE) of Control P. onkodes (AC4). (a) Overview of experimental growth, pre-experimental growth and transition zone (bracket). Cells at the surface do not have dolomite. White box enlarged in (b). (b) Cells in experimental growth have no dolomite infill. Cells below experimental growth have dolomite lining the cells but the centres are in-filled with aragonite. White box enlarged in (c), black box enlarged in (e). (c) Close up of cell infill by aragonite within the dolomite lining. (d) Dolomite lined cell in transition zone with aragonite infill. (e) Patch of crust below experimental growth with aragonite infill. (f) Close up of dolomite-lined cell with aragonite infill. Scale bars: (a) and $(\mathbf{b})=20$ microns, $(\mathbf{c})$ and $(\mathbf{f})=1$ micron, $(\mathbf{d})=2$ microns, $(\mathbf{e})=10$ microns

post-deposition Mg enrichment, it occurs relatively contemporaneously with growth.

The consistency of $\mathrm{Mg}$ composition across $P$. onkodes and new settlement CCA from pre-industrial to high $\mathrm{CO}_{2}$ treatments does not provide support for the theory that $\mathrm{Mg}-\mathrm{C}$ organisms will take up less $\mathrm{Mg}$ under higher $\mathrm{CO}_{2}$ conditions (Andersson et al., 2008). Instead our results agree with the response of $P$. onkodes in an 8-week laboratory aquarium experiment which also showed no change in $\mathrm{mol} \% \mathrm{MgCO}_{3}$ in pigmented growth with $\mathrm{CO}_{2}$ levels up to $1225 \mu \mathrm{atm}$ (DiazPulido et al., 2014). Those CCA were not embedded in resin and were grown in higher temperatures $\left(28\right.$ and $\left.30^{\circ}\right)$. Both these aquarium experimental results are in agreement with new settlement $\mathrm{CCA}$ in $\mathrm{CO}_{2}$-enriched flow through systems (Kuffner et al., 2008). This consistency of mol \% $\mathrm{MgCO}_{3}$ suggests there is a strong biological control on $\mathrm{Mg}$ uptake under variable $\mathrm{CO}_{2}$ concentrations and no detectable plastic response to $\mathrm{CO}_{2}$ within the experimental ranges. The ab- sence of change across treatments for $\mathrm{mol} \% \mathrm{MgCO}_{3}$ in the new settlement CCA, none of which have dolomite, suggests that the similar apparent lack of response of the mol \% $\mathrm{MgCO}_{3}$ in the white crusts to $\mathrm{CO}_{2}$ treatments is unrelated to the presence of dolomite. The lack of difference between preindustrial, medium and high treatments in the 6-month crust sample set suggests that no trends have been missed with the absence of the control group.

\subsection{Comparison to other studies}

The results from the $P$. onkodes are in contrast to the decreased Mg composition for tropical branching Neogoniolithon sp. (Ries, 2011). This form of Neogoniolithon is not abundant in the high-energy environments that $P$. onkodes dominates. However, the $\mathrm{mol} \% \mathrm{MgCO}_{3}$ measured in the Neogoniolithon control $\left(\sim 18.7-21.3 \mathrm{~mol} \% \mathrm{MgCO}_{3}\right)$ was much higher and with greater range than that measured for $P$. onkodes in this experiment (pre-experimental crust 

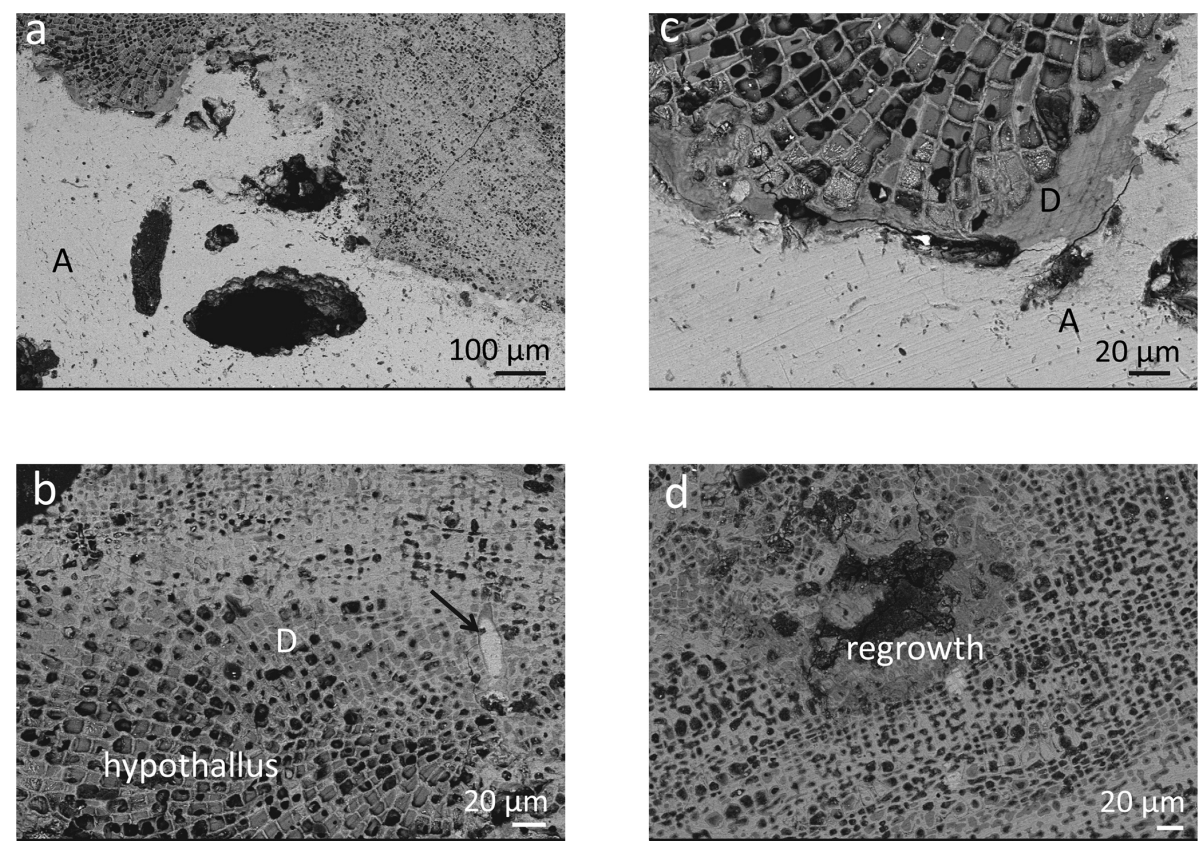

Figure 8. SEM (BSE) of varied mineral fabrics in CCA. (a) Alteration of base of CCA crust by bacteria to aragonite (Diaz-Pulido et al., 2014), remnant CCA cells are visible in the aragonite (A) confirming it was CCA crust and not coral substrate. (b) Hypothallus cells grow parallel to substrate then grow vertically and are in-filled with dolomite (D). In-fill of micro-borer trace by aragonite and dolomite rim (arrow). (c) Band of dolomite between aragonite alteration and undamaged cells. (d) Damaged crust has been in-filled with new cell growth rich in dolomite. Scale bars: $(\mathbf{a})=100$ microns, $(\mathbf{b}, \mathbf{c})$ and $(\mathbf{d})=20$ microns.

17.2-17.9, 3-month crust 16-16.8, new settlement 14.4$15.3 \mathrm{~mol} \% \mathrm{MgCO}_{3}$ Tables S1, S3 and S4). The mol \% $\mathrm{MgCO}_{3}$ in the Neogoniolithon decreased to $18.7-16.7 \mathrm{~mol} \%$ at $903 \mu \mathrm{atm} \mathrm{CO}_{2}$ (equivalent $\mathrm{CO}_{2}$ levels as our highest treatment) but only decreased by another $1.3 \mathrm{~mol} \% \mathrm{MgCO}_{3}$ on average (range $17.3-16.0 \mathrm{~mol} \% \mathrm{MgCO}_{3}$ ) with an extra $1962 \mu \mathrm{atm}\left(2865 \mu \mathrm{atm} \mathrm{CO}_{2}\right)$. Thus, the lowest $\mathrm{Mg}$ levels for the Neogoniolithon in the highest $\mathrm{CO}_{2}$ treatments were comparable to our results for control (and treatments) and to other $P$. onkodes collected from the Great Barrier Reef (Nash et al., 2011; Diaz-Pulido et al., 2014). This raises the possibility that $\mathrm{CCA} \mathrm{Mg}-\mathrm{C}$ levels are susceptible to change as $\mathrm{CO}_{2}$ rises but only for levels higher than a stable baseline, which for the tropical corallines may be in the range of $\sim 16-17.5 \mathrm{~mol} \%$ $\mathrm{MgCO}_{3}$. Egilsdottir et al. (2012) working on the temperate articulated coralline Corallina elongata reported a significant decrease in $\mathrm{Mg}$ content for new structures formed under $\mathrm{CO}_{2}$ 550-1000 $\mu$ atm. For tips, branches and basal parts formed under the enriched $\mathrm{CO}_{2}, \mathrm{Mg}$ content ranged from 14.7-15.9 mol \% $\mathrm{MgCO}_{3}$ and was not significantly different from controls (15.7, 15.2, $15.4 \mathrm{~mol} \% \mathrm{MgCO}_{3}$, respectively). On the other hand, structures growing off the base exhibited $16 \mathrm{~mol} \% \mathrm{MgCO}_{3}$ under control conditions but reduced in the tips, branches and basal plates of these new structures $\left(15.1,14.9,15.3 \mathrm{~mol} \% \mathrm{MgCO}_{3}\right)$ at $550 \mu \mathrm{atm} \mathrm{CO}_{2}$. These results suggest there is a different calcification process for the new structures compared to the tips, branches and basal parts and that this calcification process is sensitive to $\mathrm{CO}_{2}$ but only up to $550 \mu \mathrm{atm}$. Research on temperate coralline Lithothamnion glaciale showed no change in $[\mathrm{Mg}]$ for new growth over 80 days in reduced pH 7.7 treatments (Kamenos et al., 2013).

Work on $\mathrm{CO}_{2}$ influences on coralline algae structure has to date been on temperate corallines (e.g. Burdett et al., 2012; Egilsdottir et al., 2012; Ragazzola et al., 2012, 2013; Hofmann et al., 2012; Kamenos et al., 2013). Experiments on living tropical CCA calcification have focused on weight changes (e.g. Anthony et al., 2008; Comeau et al., 2013; Johnson et al., 2014) and impacts on existing crust mineralogy (Diaz-Pulido et al., 2014). There is little specific information known about calcification processes in tropical crustose corallines. However, as this study and previous studies on mineralogy (Nash et al., 2011, 2013b; Diaz-Pulido et al., 2014) show, carbonates in CCA are not only Mg-calcite but can also include dolomite, magnesite and aragonite. It is clear that the net mass of CCA is a result of multiple mineral-forming processes. While all form within the biological structure it seems unlikely that infill dolomite, magnesite and aragonite are all the result of organism-controlled calcification processes and instead are biologically induced. Thus, experimental net weight changes for $P$. onkodes may not always be a reflection of changes for only Mg-calcite calcification and/or dissolution.

Aragonite can form as a result of parasitic endolithic bacterial activity within the CCA (Diaz-Pulido et al., 2014) and 
contribute to measured weight gain. In the Diaz-Pulido et al., study (2014) weight change was due in part to a mix of bacterial-driven carbonate destruction processes and abiotic aragonite precipitation as a result of calcium mobilisation by the endolithic bacteria. In the Johnson et al. (2014) study weight gain by CCA from locations downstream of the reef front was interpreted as indicating acclimatisation. However, if there were more endolithic bacteria present in their downstream CCA than the reef front CCA, it is possible that the experimental fluctuating conditions with elevated $\mathrm{CO}_{2}$ activated bacterial processes and the lower $\mathrm{CO}_{2}$ resulted in increased re-precipitation of mobilised calcium as aragonite (aragonite re-precipitation transforms the porous crust to dense cement) which could account for a proportion of the weight gain. Therefore, it is problematic to presume acclimatisation based on weight gain without knowing how the weight was gained. The published experiments referred to in this discussion were all conducted prior to the discovery of dolomite, magnesite and aragonite in $P$. onkodes, but future studies should consider the more complex nature of mineral composition of $P$. onkodes when attempting to explain weight changes and calcification (e.g. Nash et al., 2013).

The varied responses of the tropical and temperate corallines to altered $\mathrm{CO}_{2}$ indicate that the uptake of $\mathrm{Mg}$ by CCA is not consistent across all species or even within the same organism (Egilsdottir et al., 2012). Furthermore, the use of different methods of measuring $\mathrm{Mg}$ concentration potentially complicates comparisons across data sets. Ries (2011) and our study used XRD to determine mol $\% \mathrm{MgCO}_{3}$. This measurement only returns mol \% for the $\mathrm{Mg}$-Calcite component and is not influenced by the presence of $\mathrm{Mg}$ in other forms, e.g. dolomite or within organics, or diluted by the presence of aragonite. Kamenos et al. (2013) used Raman spectroscopy for identifying mol $\% \mathrm{MgCO}_{3}$ changes, this method is not widely used for coralline algae mineralogy studies. Egilsdottir et al. (2012) used inductively coupled plasma- atomic emission spectroscopy (ICP-AES) to quantify bulk Mg and Ragazzola et al. (2013) used electron microprobe to obtain an average elemental composition for $\mathrm{Mg} / \mathrm{Ca}$ ratios. These methods return bulk $\mathrm{Mg}$ for the total sample or portion under the electron beam and may be skewed by undetected aragonite, common in corallines (Smith et al., 2012; Nash et al., 2013b) or presence of $\mathrm{Mg}$ not within the $\mathrm{Mg}$ calcite, (e.g. Caragnano et al., 2014).

\subsection{Dolomite formation within 12 weeks}

Prior to the discovery of bio-mediated dolomite in association with bacteria (Vasconcelos and Mackenzie, 1997) and CCA (Nash et al., 2011), dolomite was thought to form by chemical alteration of limestone over geological time frames, e.g. thousands to millions of years (e.g. Saller, 1984). Though it has also been controversially argued that dolomite was the primary precipitation in some ancient dolomite formations (Tucker, 1982). Our experimental results demonstrate that bio-mineralised dolomite formation is rapid and occurs contemporaneously with the surrounding limestone formation. The apparent reduction in dolomite formation in the experimental conditions compared to the pre-experimental growth indicates that there is also a rapid response to changing environmental conditions. Accordingly, any interpretation of past environments made using dolomite that may have had a biological origin, i.e. dolomite in formerly shallow tropical environments, would need to take into account this potentially rapid formation and response to environmental change.

\subsection{Implications for interpreting the geological past}

The absence of a significant effect of $\mathrm{CO}_{2}$ on dolomite formation in this experiment suggests that the observed correlation in the geologic rock record of dolomite and greenhouse conditions may not be a direct result of high $\mathrm{CO}_{2}$ driving increased primary bio-mineralised dolomite formation. However, as noted in previous work (Nash et al., 2013a; DiazPulido et al., 2014), dolomite is more resistant to chemical dissolution and biological erosion than $\mathrm{Mg}$-calcite (and presumably also calcite). Therefore, the positive correlation of dolomite and greenhouse epochs in the rock record (e.g. MacKenzie et al., 2008; Wilkinson and Given, 1986) may be due in part to preferential preservation of bio-mineralised dolomite compared to surrounding skeletal material, rather than $\mathrm{CO}_{2}$ or temperature-driven biological processes leading to increased dolomite formation. Furthermore, during greenhouse times, sea level was higher thereby providing greater area of warm shallow (epeiric) seas and thus more accommodation space for calcifying algae that may have formed dolomite. While past primary bio-mineralised dolomite levels may not have been directly linked to $\mathrm{CO}_{2}$ levels, there is certainly support from other work (Nash et al., 2013a; Diaz-Pulido et al., 2014) for indirect biologically associated processes leading to increased abundance of bio-mineralised dolomite under higher $\mathrm{CO}_{2}$ conditions.

\subsection{Changes in calcification in experimental tanks}

Considering the aragonite observed in the crust where the CCA was transferred to the experimental tanks, it may be that interruptions to normal growth after transfer to experimental tanks allowed seawater to penetrate into the shallow surface layer resulting in an alteration of $\mathrm{Mg}-\mathrm{C}$ to aragonite. Previous experiments on calcification rates of $\mathrm{CCA}$ found that rates of photosynthesis, and production of inorganic and organic carbon, were significantly lower in experimental tanks than in situ (Chisholm, 2003). A decrease in photosynthesis and calcification rates may be the explanation for the observed differences in calcified crust in this study, although the exact mechanism leading to the change is not known. The absence of the organic film in the experimental growth (Fig. 5c) raises the possibility that it is the absence of these organics that has led to the observed differences in calcification. This organic 
film is consistently present on the pre-experimental growth and consistently absent from the experimental growth. Thus, it is unlikely to be a sample preparation artifact, although the preparation method may make this film more readily visible than if the samples had been fractured leaving an uneven surface. Reduced organic production may also lead to less dolomite as experiments have shown that dolomite nucleates on polysaccharides produced by red algae (Zhang et al., 2012). It is probable that our experimental results understate how much dolomite could be formed in the open marine environment over a 3 and 6-month period.

The observation that the change to experimental tanks coincided with changes in CCA calcification has implications for extrapolating experimental results back to the natural environment. There is a substantial change in the ultrastructure and secondary mineralisation (i.e. formation of dolomite) processes. While comparisons between treatments are reliable, exact rates of calcification for $P$. onkodes are likely to be understated in experimental conditions compared to the open reef. This is an area that requires further work to determine what is causing this difference in calcification and if it is common to all similar experiments. Flow and wave energy will be important factors that influence the calcification processes and should also be considered in future aquarium designs that seek to test the effects of future acidification scenarios on CCA's.

\subsection{What does Mol \% Mg-calcite mean for the CCA physiology and reef processes in a changing climate?}

There have been no studies to date that explore the drivers of organism-controlled calcification in the key reef-builder $P$. onkodes and what role the $\mathrm{Mg}$ content plays in this. Thus, it is unclear at this time what influence the mol $\% \mathrm{MgCO}_{3}$ has on CCA physiology and reef processes and even more difficult to anticipate what may happen in the future in a changing climate. Early studies on Mg-C CCA dissolution rates (Plummer and Mackenzie, 1974; Bischoff et al., 1987) used CCA that had dolomite and possibly magnesite (see Nash et al., 2013 for discussion). Those results were a mix of dissolution rates for the 2-3 different $\mathrm{Mg}$ minerals, not just for $\mathrm{Mg}$ calcite with different phases of $\mathrm{mol} \% \mathrm{MgCO}_{3}$ as was interpreted. Much of our present understanding of biogenic $\mathrm{Mg}-\mathrm{C}$ dissolution is based on those interpretations (e.g. Andersson et al., 2008). Considering how recent work on CCA dissolution has revealed that a complex suite of interacting mineral, biological, bacterial and chemical factors contribute to net dissolution responses (Nash et al., 2013; Reyes-Nivia et al., 2014; Diaz-Pulido et al., 2014) it has become apparent that the prevailing theory that higher $\mathrm{Mg}$ content leads to lower stability is probably not applicable to tropical $P$. onkodes. Indeed there have been no dissolution experiments comparing the dissolution rates of CCA with different mol \% $\mathrm{MgCO}_{3}$ to test the correlation of dissolution rates to $\mathrm{Mg}$ content of Mg-C.

\subsection{Implications for reef management}

Finding that dolomite is not affected by ocean acidification in these 3 and 6-month experiments is good news for the survival of CCA species $P$. onkodes under predicted ocean acidification conditions. Dolomite confers stability on the CCA and facilitates its reef-building role (Nash et al., 2013a) as well as being resistant to bacterial bio-erosion (Diaz-Pulido et al., 2014). At this time exact drivers of CCA dolomite formation have not been identified. It seems most likely that dolomite formation is related to provision of a suitable organic substrate, probably being the polysaccharides derived from red algae for agar (Nash et al., 2013a; Zhang et al., 2012). For coral reef management, it is necessary to understand what environmental conditions negatively impact dolomite formation. CCA crust formation is likely to suffer negative affects from reduced recruitment, increased bleaching, bio-erosion and dissolution under higher $\mathrm{CO}_{2}$ and temperatures (Kuffner et al., 2011; Diaz-Pulido et al., 2012). However, understanding the conditions that negatively impact dolomite formation may enable more effective assessments of the risk that $\mathrm{CO}_{2}$-driven ocean acidification may pose to important reef-builders such as $P$. onkodes. Identifying the drivers and constraints of CCA dolomite formation is an area of research that has not yet been initiated and as such, there is a long way to go to understand what conditions may negatively impact on CCA dolomite formation.

\section{The Supplement related to this article is available online at doi:10.5194/bg-12-5247-2015-supplement.}

Acknowledgements. Thanks to Frank Brink and the Centre for Advanced Microscopy at the Australian National University for assistance with SEM. Thanks to Florita Flores, Michelle Liddy, Julia Strahl, Paulina Kaniewska and Jordan Hollarsmith for aquarium maintenance and experimental assistance. Funding for the experimental work was provided by the Australian Institute of Marine Science and a Super Science Fellowship from the Australian Research Council. Support for mineral analysis was provided by the Electronic Materials Engineering department at the Research School of Physics, Australian National University.

Edited by: D. Gillikin

\section{References}

Adey, W. H., Halfar, J., and Williams, B.: The coralline genus Clathromorphum Foslie emend, Adey: Biological, physiological, and ecological factors controlling carbonate production in 
an Arctic-Subarctic climate archive, Smithsonian contributions to the marine sciences; number 40, 1-41, 2013.

Andersson, A. J., Mackenzie, F. T., and Bates, N. R.: Life on the margin: implications of ocean acidification on Mg-calcite, high latitude and cold-water marine calcifiers, Mar. Ecol. Prog. Ser, 373, 265-273, 2008.

Anthony, K. R. N., Kline, D. I., Diaz-Pulido, G., Dove, S., and Hoegh-Guldberg, O.: Ocean acidification causes bleaching and productivity loss in coral reef builders, PNAS, 105, 1744217446, 2008.

Bischoff, W. D., Mackenzie, F. T., and Bishop, F. C.: Stabilities of synthetic magnesian calcites in aqueous solution: Comparison with biogenic materials, Geochim. Cosmochim. Acta. 51, 14131423, 1987.

Burdett, H. L., Hennige, S. J., Francis, F. T. Y., and Kamenos, N. A.: The photosynthetic characteristics of red coralline algae, determined using pulse amplitude modulation (PAM) fluorometry, Mar. Biol. Res., 8, 756-763, 2012.

Caragnano, A. D., Basso, D. E., Jacob, D., Storz, G., Rodondi, F., Benzoni, and Dutrieux, E.: The coralline red alga Lithophyllum kotschyanum f. affine as proxy of climate variability in the Yemen coast, Gulf of Aden (NW Indian Ocean), Geochim. Cosmochim. Ac., 124, 1-17, 2014.

Chisholm, J. R. M.: Primary productivity of reef-building crustose coralline algae, Limnol. Oceanogr., 48, 1376-1387, 2003.

Comeau, S., Edmunds, P. J., Spindel, N. B., and Carpenter, R. C.: The responses of eight coral reef calcifiers to increasing partial pressure of $\mathrm{CO}_{2}$ do not exhibit a tipping point, Limnol. Oceanogr, 58, 388-398, 2013.

Darrenougue, N., De Deckker, P., Eggins, S., and Payri, C.: Seasurface temperature reconstruction from trace elements variations of tropical coralline red algae, Quaternary Sci. Rev., 93, 34-46, 2014.

Diaz-Pulido, G., Anthony, K., Kline, D. I., Dove, S., and HoeghGuldberg, O.: Interactions between ocean acidification and warming on the mortality and dissolution of coralline algae, J. Phyc., 48, 32-39, 2012.

Diaz-Pulido, G., Nash, M. C., Anthony, K. R. N., Bender, D., Opdyke, B. N., Reyes-Nivia, C., and Troitzsch, U.: Greenhouse conditions induce mineralogical changes and dolomite accumulation in coralline algae on tropical reefs, Nat. Comms., 5, 1-9, 2014.

Egilsdottir, H., Noisette, F., Noel, L. M., Olafsson, J., and Martin, S.: Effects of $p \mathrm{CO}_{2}$ on physiology and skeletal mineralogy in a tidal pool coralline alga Corallina elongate, Mar. Biol., 160, 2103-2112, 2012.

Fietzke, J., Ragazzola, F., Halfar, J., Dietze, H., Foster, L. C., Hansteen, T. H., Eisenhauer, A., and Steneck., R. S.: Centuryscale trends and seasonality in $\mathrm{pH}$ and temperature for shallow zones of the Bering Sea, P. Natl. Acad. Sci., 112, 2960-2965, 2015.

Gaines, A.: Protodolomite redefined, J. Sed. Pet., 47, 543-546, 1977.

Given, R. K. and Wilkinson, B. H.: Dolomite abundance and stratigraphic age: constraints on rates and mechanisms of Phanerozoic dolostone formation, J. Sediment. Petrol., 57, 1068-1078, 1987.

Halfar, J., Adey, W. H., Kronz, A., Hetzinger, S., Edinger, E., and Fitzhugh, W. W.: Arctic sea-ice decline archived by multicentury annual-resolution record from crustose coralline algal proxy, $\mathrm{P}$. Natl. Acad. Sci., 110, 19737-19741, 2013.

Hofmann, L. C., Yildiz, G., Hanelt, D., and Bischof, K.: Physiological responses of the calcifying rhodophyte, Corallina officinalis (L.), to future $\mathrm{CO}_{2}$ levels, Mar. Biol., 159, 783-792, 2012.

Howard, W. R., Nash, M., Anthony, K., Schmutter, K., Bostock, H., Bromhead, D., and Williamson, J.: Ocean acidification, in: A Marine Climate Change Impacts and Adaptation Report Card for Australia 2012, edited by: Poloczanska, E., Hobday, A., and Richardson, A., Centre for Australian Weather and Climate Research, Hobart, TAS, 2012.

Jones, B., Luth, R. W., and McNeil, A. J.: Powder X-ray diffraction analysis of homogeneous and heterogeneous sedimentary dolostones, J. Sed. Res., 71, 790-799, 2001.

Johnson, M. D., Moriarty, V. W., and Carpenter, R. C.: Acclimatization of the Crustose Coralline Alga Porolithon onkodes to variable $p \mathrm{CO}_{2}$, PLoS ONE, 9, e87678, doi:10.1371/journal.pone.0087678, 2014.

Kaczmarek, S. E. and Sibley, D. F.: On the evolution of dolomite stoichiometry and cation order during high-temperature synthesis experiments: An alternative model for the geochemical evolution of natural dolomites, Sed. Geol., 240, 30-40, 2011.

Kamenos, N. A., Cusack, M., and Moore, P. G.: Coralline algae are global palaeothermometers with bi-weekly resolution, Geochim. Cosmochim. Acta, 72, 771-779, 2008.

Kamenos, N. A., Burdett, H. L., Aloisio, E., Findlay, H. S., Martin, S., Longbone, C., Dunn, J., Widdicombe, S., and Calosi, P.: Coralline algal structure is more sensitive to rate, rather than the magnitude, of ocean acidification, Global Change Biol., 19, 3621-3628, 2013.

Kuffner, I. B., Andersson, A. J., Jokiel, P. L., Rodgers, K. S., and Mackenzie, F. T.: Decreased abundance of crustose coralline algae due to ocean acidification, Nat. Geosci., 1, 114-117, 2007.

Mackenzie, F. T., Arvidson, R. S., and Guidry, M. W.: Chemostatic models of the ocean atmosphere-sediment system through Phanerozoic time, Mineral Mag., 72, 329-332, 2008.

Nash, M. C., Troitzsch, U., Opdyke, B. N., Trafford, J. M., Russell, B. D., and Kline, D. I.: First discovery of dolomite and magnesite in living coralline algae and its geobiological implications, Biogeosciences, 8, 3331-3340, doi:10.5194/bg-8-3331-2011, 2011.

Nash, M. C., Opdyke, B. N., Troitzsch, U., Russell, B. D., Adey, W. H., Kato, A., and Kline, D. I.: Dolomite-rich coralline algae in reefs resist dissolution in acidified conditions, Nat. Climate Change, 3, 268-272, 2013a.

Nash, M. C., Opdyke, B. N., Wu, Z., Xu, H., and Trafford, J. M.: Simple x-ray diffraction techniques to identify mg-calcite, dolomite, and magnesite in tropical coralline algae and assess peak asymmetry, J. Sediment. Res., 83, 1085-1099, 2013b.

Orr, J.: Recent and future changes in ocean carbonate chemistry, in: Ocean Acidification, edited by: Gattuso, J. P. and Hansson, L., 3, 41-66, 2011.

Plummer, L. N. and Mackenzie, F. T.: Predicting mineral solubility from rate data: Application to the dissolution of magnesian calcites, Am. J. Sci., 274, 61-83, 1974.

Pueschel, C. M., Judson, B. L., and Wegeberg, S. : Decalcification during epithallial cell turnover in Jania adhaerens (Corallinales, Rhodophyta)., Phycologia, 44, 156-162, 2005.

Ragazzola, F., Foster, L. C., Form, A., Anderson, P. S., Hansteen, T. H., and Fietzke, J.: Ocean acidification weakens the structural 
integrity of coralline algae, Global Change Biol., 18, 2804-2812, 2012.

Ragazzola, F., Foster, L. C., Form, A. U., Buscher, J., Hansteen, T. H., and Fietzke, J.: Phenotypic plasticity of coralline algae in a high $\mathrm{CO}_{2}$ world, Ecol. Evol., 3, 3436-3446, 2013.

Ramirez-Reinat, E. L. and Garcia-Pichel, F.: Characterization of a marine cyanobacterium that bores into carbonates and the redescription of the genus Mastigocoleus, J. Phycol., 48, 740-749, 2012.

Reyes-Nivia, C., Diaz-Pulido, G., and Dove, S.: Relative roles of endolithic algae and carbonate chemistry variability in the skeletal dissolution of crustose coralline algae, Biogeosciences, 11, 4615-4626, doi:10.5194/bg-11-4615-2014, 2014.

Ries, J. B.: Skeletal mineralogy in a high $\mathrm{CO}_{2}$ world, J. Exp. Mar. Biol. Ecol., 403, 54-64, 2011.

Saller, A. H.: Petrologic and geochemical constraints on the origin of subsurface dolomite, Enewetak Atoll: An example of dolomitization by normal seawater, Geology, 12, 217-220. 1984.

Smith, A. M., Sutherland, J. E., Kregting, L., Farr, T. J., and Winter, D. J.: Phylomineralogy of the Coralline red algae: Correlation of skeletal mineralogy with molecular phylogeny, Phytochemistry, 81, 97-108, 2012.

Steneck, R. S.: The ecology of coralline algal crusts: convergent patterns and adaptative strategies, Ann. Rev. Ecol. Syst., 17, 273303, 1986.
Tucker, M. E.: Precambrian dolomites: petrographic and isotopic evidence that they differ from Phanerozoic dolomites, Geology, 10, 7-12, 1982.

Uthicke, S., Pecorino, D., Albright, R., Negri, A. P., Cantin, N., Liddy, M., Dworjanyn, S., Kamya, P., Byrne, M., and Lamare, M.: Impacts of Ocean Acidification on Early Life-History Stages and Settlement of the Coral-Eating Sea Star Acanthaster planci, PLoS ONE, 8, e82938, doi:10.1371/journal.pone.0082938.t005, 2013.

Vasconcelos, C. and McKenzie, J. A.: Microbial mediation of modern dolomite precipitation and diagenesis under anoxic conditions (Lagoa Vermelha, Rio de Janeiro, Brazil), J. Sediment. Res., 67, 378-390, 1997.

Wilkinson, B. H. and Given, R. K.: Secular variation in abiotic marine carbonates: Constraints on Phanerozoic atmospheric carbon dioxide contents and oceanic $\mathrm{Mg}$ / Ca ratios, J. Geol., 94, 321333, 1986.

Zhang, F., Xu, H., Konishi, H., Shelobolina, E. S., and Roden, E. E.: Polysaccharide-catalyzed nucleation and growth of disordered dolomite: A potential precursor of sedimentary dolomite, Am. Mineral., 97, 556-567, 2012.

Zhang, F., Xu, H., Shelobolina, E. S., Konishi, H., Converse, B., Shen, Z., and Roden, E. E.: The catalytic effect of bound extracellular polymeric substances excreted by anaerobic microorganisms on Ca-Mg carbonate precipitation: Implications for the “dolomite problem", Am. Mineral., 100, 483-494, 2015. 